\title{
THE ALLEGORY OF DYNASTIC SUCCESSION ON THE FAÇADE OF THE PRAGUE BELVEDERE (1538-1550)*
}

\author{
JAN BAŽANT
}

\begin{abstract}
The paper analyses a unique relief sculpture which decorates the Prague Belvedere built by Ferdinand I. It represents an old man on horseback passing the globe to a young man standing in front of him. The scene may be interpreted as the allegory of dynastic succession. The adjoining reliefs corroborate this hypothesis, on the left we find the coat of arms of the Bohemian Kingdom and on the right Andromeda liberated by Perseus, alter ego of Ferdinand I.
\end{abstract}

Keywords: Ferdinand I; Renaissance art; relief sculpture; allegory; dynasty

Ferdinand I, Archduke of Austria, King of Bohemia and Hungary and King of the Romans, started to build the Prague Belvedere in the Garden of Prague Castle in 1538. In 1550, the ground floor of this villa all'antica was completed (Bažant 2003a; Bažant 2005; Kalina, Kotátko 2011: 64-73). Column arcades on all four sides received rich sculptural decoration, which was the work of Paolo della Stella, who came to Prague from Genoa (Bažant 2003b; Bažant 2006: 99-218; Chlíbec 2011: 88-89; Bažant, Bažantová 2014: 68-219; Bažant 2016). In this paper I would like to present a new interpretation of the relief sculpture in the second spandrel of the north façade (Fig. 1). Its theme is unique. From the right, a bearded man in ancient armour arrives on horseback and holds something in his outstretched right hand. A beardless young man is standing in front of the rider and holds the same object with his raised hands. He is also represented in ancient armour with a sabre on his left hip.

In my previous publications, I interpreted these two men as Bellerophon and Iobates (Bažant 2006: 118-119; Bažant, Bažantová 2014: 207-208). I argued that Bellerophon was raising a bag containing a letter, to hand it to Iobates on horseback. The scene would be thus loosely connected with the series representing Perseus's myth which we

\footnotetext{
* The work was supported by the long-term strategic development financing of the Institute of Philosophy of the Academy of Sciences of the Czech Republic (RVO: 67985955). I am grateful for the helpful comments and criticism of Renate Leggatt-Hofer and anonymous readers of the Journal of the Warburg and Courtauld Institutes and Graecolatina Pragensia.
} 
find on all figural reliefs in spandrels of the north façade (Bažant 2016). Perseus and Bellerophon never met, but Bellerophon tamed Pegasus, the winged horse born when Perseus beheaded Medusa. There are altogether sixth spandrel reliefs on the northern façade, Pegasus represented on the fifth spandrel thus makes a pair with the scene on the second spandrel.

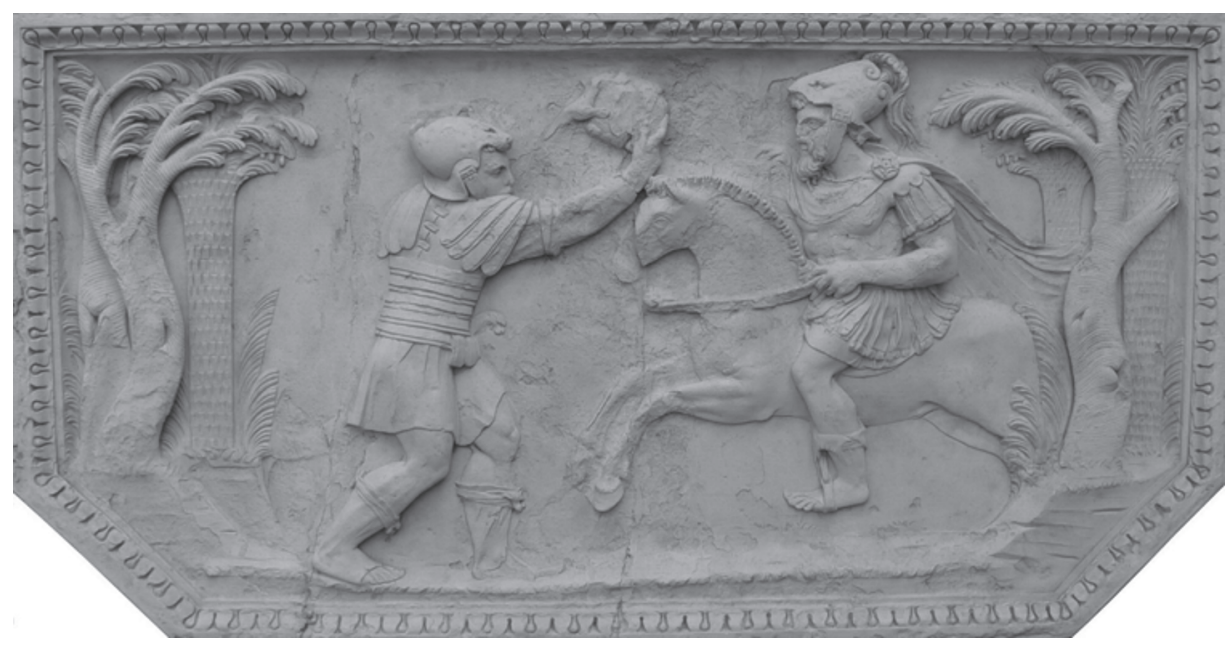

Fig. 1. Paolo della Stella, Allegory of Dynastic Succession, second spandrel of the northern façade of the Prague Belvedere (from left to right), sandstone relief sculpture, 1538-1550.

Today, I am convinced that the object that the two men on the second spandrel relief are holding is not a bag with a letter but a globe (Fig. 2). Consequently, the relief sculpture represents the allegory of dynastic succession. The model for this scene was an incorrect reconstruction by the Venetian numismatist, Sebastiano Erizzo, of the reverse of the sestertius of the ancient Roman Emperor, Titus, minted in 80-81 AD (Fig. 3). On the original coin, a male personification of Rome stands, resting one foot on a globe, and presenting a Palladium to Emperor Titus on horseback (Cunnally 1999: 188-189; Carradice, Buttrey 2007: 209, no. 166-167). In his book of 1559, Sebastiano Erizzo published a woodcut of this coin, but in it, a globe replaced the Palladium. Erizzo explained the representation on the coin as follows: "As you can see, this coin was minted in Rome for no other reason but the glorification of Emperor Titus. The figure on horseback is Titus, and the figure at his feet is the City of Rome. Rome lays the world in the hands of the ruler, which is to say that Rome and Providence had given world rule to Titus" (Erizzo 1559: 195 ; my translation). ${ }^{1}$

1 The text and illustration were repeated in the later editions (Erizzo 1568: 256; c. 1585: 137), which means that this interpretation was accepted in the second half of the $16^{\text {th }}$ century. In the British Museum, there is a coin of this type, which was tooled to correspond to the woodcut in Erizzo's authoritative book (inv. n. R.11198). 


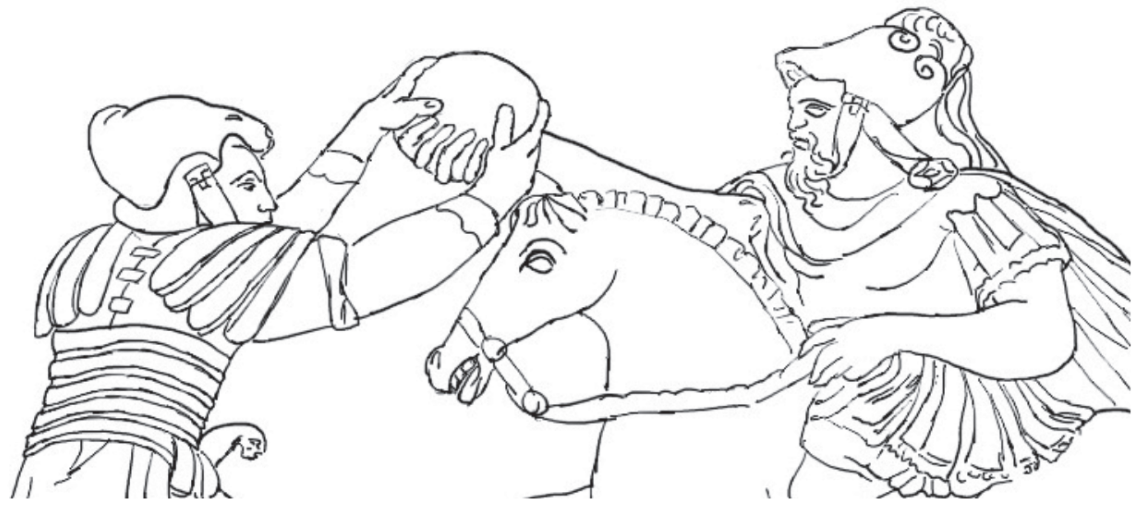

Fig. 2. Paolo della Stella, Allegory of Dynastic Succession (partial reconstruction indicating position of fingers holding the globe), 1538-1550 (drawing Nina Bažantová).

The erroneous reconstruction was inspired by a different coin from the reign of Titus: one showing the standing togate Vespasian presenting the globe to the standing togate Titus. Under the globe is a rudder, another symbol of world rule (Carradice, Buttrey 2007: 209, no. 161-162). This coin was published by Vico (Fig. 4), who shortened the inscription PROVIDENT AVGVST to PROVIDEN AVG and left out the rudder (Vico, Zantani 1548: 51; Vico 1554: LI). We find the same coin also in Du Choul's book (Fig. 5) which was published ten years later (Du Choul 1556: 68). Du Choul comments on the coin in a similar vein to Erizzo: "in ancient times, Providence was considered to be a deity ... They represented her as a woman in a long dress holding a sceptre in one hand and the globe in another ... In this way, she was represented on medals of Trajan ... The other emperors (such as Titus) represented her with a rudder and a globe, with which they denoted the rule of the world" (Du Choul 1556: 66-67; my translation). On the coin published by Vico and Du Choul, there is an inscription Providentia Augusti (Imperial Providence), which appeared on the coins of many Roman Emperors. In the sixteenth century, it was known that the orderly imperial succession was an important aspect of imperial

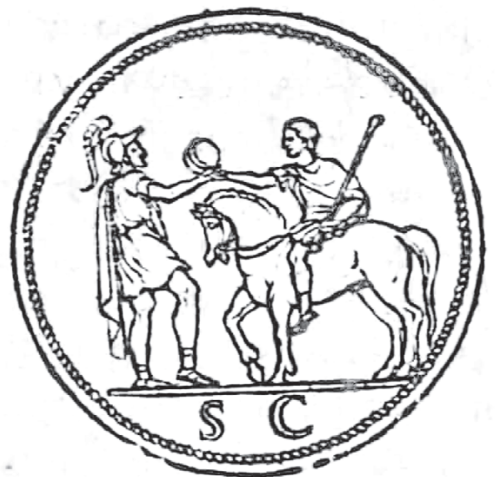

Fig. 3. Incorrect reconstruction of the reverse of the sestertius of Titus minted in 80-81 AD, woodcut (Erizzo 1559: 195). 
virtue. At the time when Paolo della Stella was working on the Prague Belvedere, neither Erizzo's nor Du Choul's books had been published. Nevertheless, Paolo della Stella (or his advisors) could have known about the incorrect reconstruction of Titus's sestertius and its symbolism from some other source, perhaps from Sebastiano Erizzo himself.

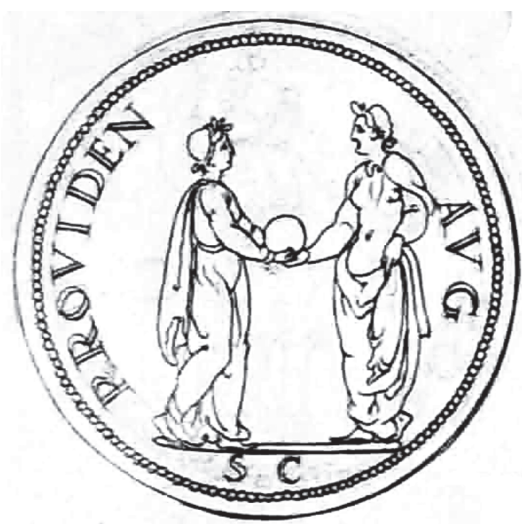

Fig. 4. Coin with Vespasian and Titus holding a globe minted in 80-81 AD, woodcut (Vico, Zantani 1548: 51).



Fig. 5. Coin with Vespasian and Titus holding a globe, woodcut (Du Choul 1556: 68).

In the relief sculpture on the Prague Belvedere, the man sitting on horseback might be a ruler who is giving the globe (world rule) to his successor, who solemnly receives it with both hands (Fig. 1-2). The Ancient Roman military uniforms of both protagonists place the scene in the distant past. The scene visualises the idea of dynastic succession in general; that is why the protagonists' physiognomies are not individualised. What is important is that world power passes smoothly from the actual ruler characterised by a beard to the younger member of the ruling dynasty who is apparently beardless. It might be an allusion to the political situation in Ferdinand I's state, which is suggested by the adjoining relief on the left. We find here the coat of arms of the Bohemian Kingdom, the double-tailed lion, which initially had a crown on its head (Fig. 6). 


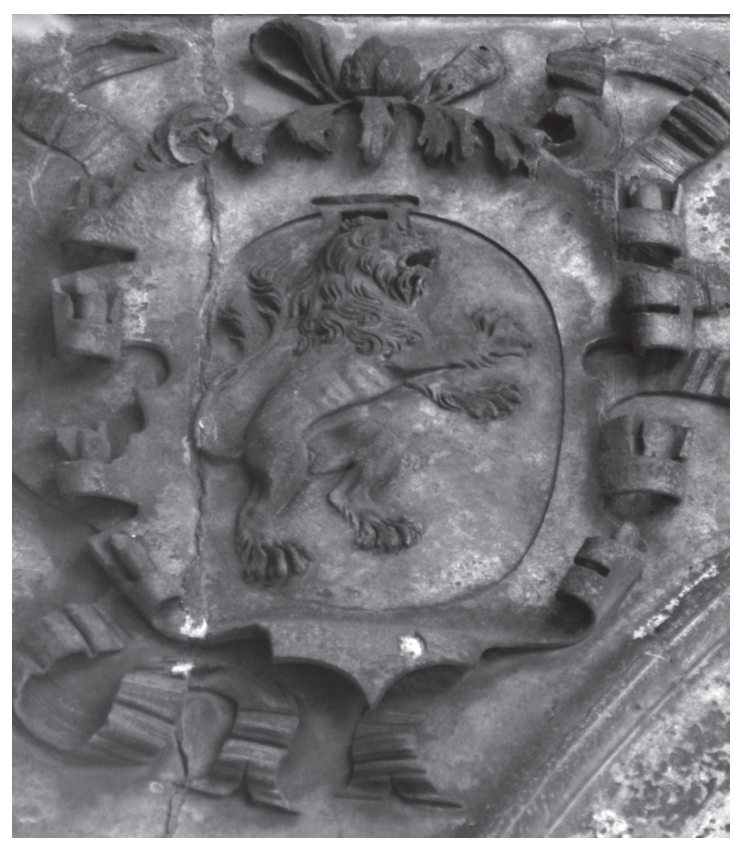

Fig. 6. Paolo della Stella, shield with the Bohemian lion, first spandrel on the northern façade of the Prague Belvedere, sandstone relief sculpture, 1538-1550.

Ferdinand had strong reasons to present his accession to the Bohemian throne as a dynastic succession. In 1515, Emperor Maximilian I arranged the marriages of his granddaughter Mary to Louis, the son of Ladislaus II, and his grandson Ferdinand to the sister of Louis II, Anna. When Ladislaus II died in the following year, Maximilian I adopted both Anna and Louis II, the latter becoming King of Bohemia and Hungary. In 1526, after the death of Louis II, the Czech estates elected Ferdinand I as Bohemian King. Czech estates argued that Anna lost her claim to her father's throne, when she married Ferdinand I. When her brother Louis II died childless, there was no legitimate heir to this Royal crown, and it was thus necessary to elect a new King. Ferdinand I had to sign a document in 1526 in which these facts were explicitly presented. Ferdinand, however, never came to terms with his status as elected King, which significantly reduced his authority. This is proven, for example, by the document of 9 September 1532, in which Anna, undoubtedly on Ferdinand I's initiative, willed the Czech and Hungarian Kingdoms to her sons (Seipel 2003: 7, no. IV). Several days later, on 17 September 1532, Ferdinand signed his last will and testament, in which he left the Czech and Hungarian Kingdoms to his son, Maximilian II (Seipel 2003: 39, no. III).

The coat of arms of the Bohemian Kingdom on the eastern end of the northern façade of the Prague Belvedere is the counterpart of the monogram, "FA", at the western end of the this façade, in the sixth spandrel (Fig. 7). The initials "FA" were apparently an important part of Ferdinand I's political propaganda and that is why they were above the original main entrance to the arcades of the Prague Belvedere. After a decade of intense pressure, Ferdinand was finally able to force the Czech political representation 
to announce that their legal interpretation of the state of affairs, which remained after Louis II's death, was incorrect. In 1545, the Czech parliament officially proclaimed that Ferdinand had not become King through elections, but through his marriage to Anna, who was the rightful heiress to the throne (Buchholtz 1968-1971: VI, 350). In an addendum to his revised testament on 4 February 1547, Ferdinand considered it necessary to emphasise that the document was in compliance with the Czech rules under which he had been elected. At that time, he argued, he had not yet known that he had acquired the Czech crown as the husband of Queen Anna, who had rightfully inherited it (Buchholtz 1968-1971: VIII, 749).

The Czech estates were very well aware of what they had lost by agreeing to the re-evaluation of Ferdinand's ascension to the Royal throne. They never came to terms with this setback and insisted that the next ruler would once again be elected by free elections. The decoration of the Prague Belvedere was in reaction to this high-principled stance of the local political representation. On its northern façade, we find the coat of arms of the Bohemian Kingdom, the scene celebrating dynastic succession, together with the two initials, "FA". This sequence of images emphasised that the Bohemian Kingdom was inherited Habsburg land. The monogram "FA" was, above all, a celebration of the founding of the Habsburg monarchy in Central Europe, where the Czech Queen played the

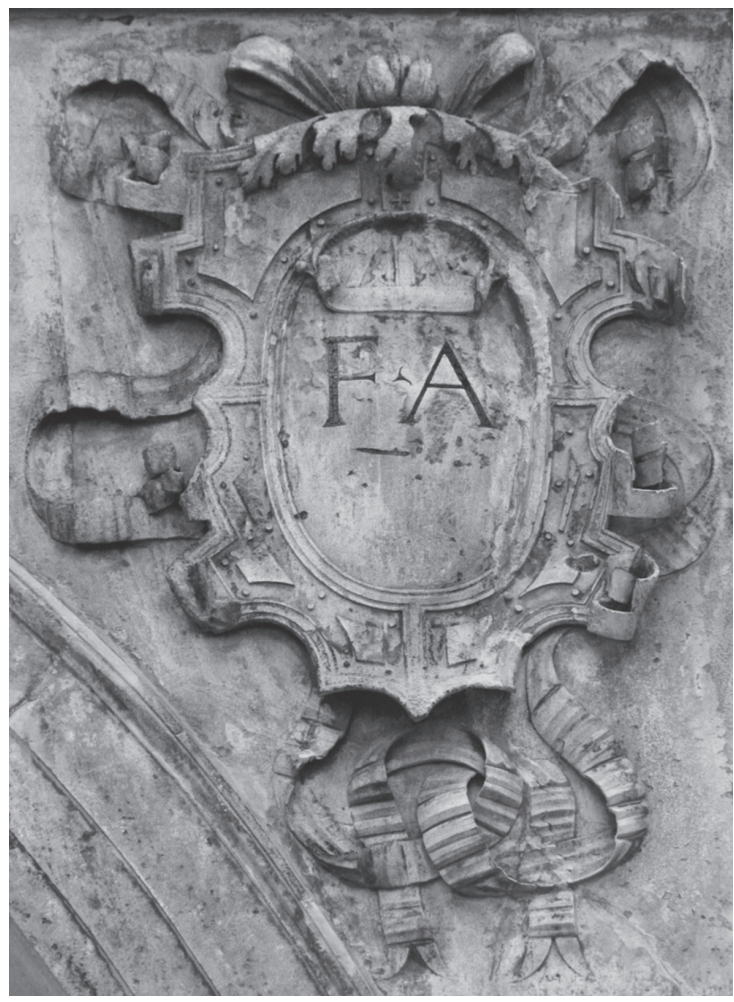

Fig. 7. Paolo della Stella, shield with monogram: FA (Ferdinand and Anna), sixth spandrel on the northern façade of the Prague Belvedere, sandstone relief sculpture, 1538-1550. 
crucial role. It was precisely due to this title, as co-founder of the new Empire, that Anna was celebrated during her time (Seipel 2003: 4, no. IV).

The scene of dynastic succession might refer not only to the Bohemian Kingdom, but also to the Holy Roman Empire. Next to the coat of arms of the Bohemian Kingdom, there is the coat of arms of the Hungarian Kingdom in the arcade spandrel at the northern end of the eastern façade. After these coats of arms of Ferdinand I as Bohemian and Hungarian King, the decoration of the arcades on the eastern façade continues with a series of scenes with Charles V and his African campaign. At the time when Ferdinand was building his Prague villa, the problem of the Imperial crown occupied Ferdinand I perhaps even more than that of the Czech and Hungarian Royal crowns.

There was an agreement that Ferdinand I would succeed Charles V as Holy Roman Emperor. Nevertheless, at the Augsburg Congress in 1547 and 1548, rumours were spread that Emperor Charles V was promoting his son Phillip II as his successor. When Charles V presented Phillip II as his successor everywhere on a European tour from 1548 to 1550, Ferdinand must have taken it very hard (Calvete de Estrella 2001). The colonnade and the spandrel relief sculpture of the Prague Belvedere were completed at the same time, 1548-1550. The uncertainty concerning Charles V's plans for the Empire did not end until 1555, when he suddenly relinquished the imperial position to his younger brother, as had been initially negotiated (Seipel 2003: 143-144).

The reading of the relief in the second spandrel of the northern façade of the Prague Belvedere as an Allegory of Dynastic Succession is suggested not only by the adjoining relief on the left, but also by that on the right. In the arcade spandrel to the right of the Allegory of Dynastic Succession, we find the Liberation of Andromeda (Fig. 8). Paolo della Stella represented her in a very peculiar way; she is bent forward and lashed to a tree by a wide strip of cloth wrapped around her elbow. In European sculpture, there is no analogy for Perseus's liberation of Andromeda with hands tied in this way and we must ask what may be the meaning of this scene.

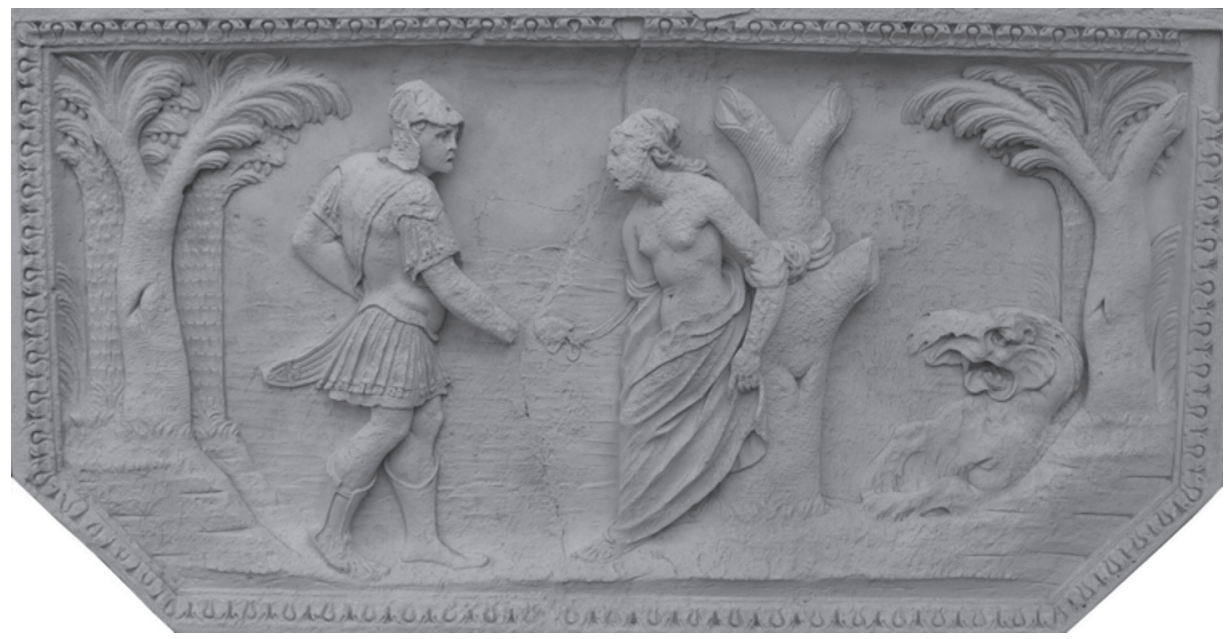

Fig. 8. Paolo della Stella, Perseus Liberating Andromeda, third spandrel of the northern façade of the Prague Belvedere, sandstone relief sculpture, 1538-1550. 


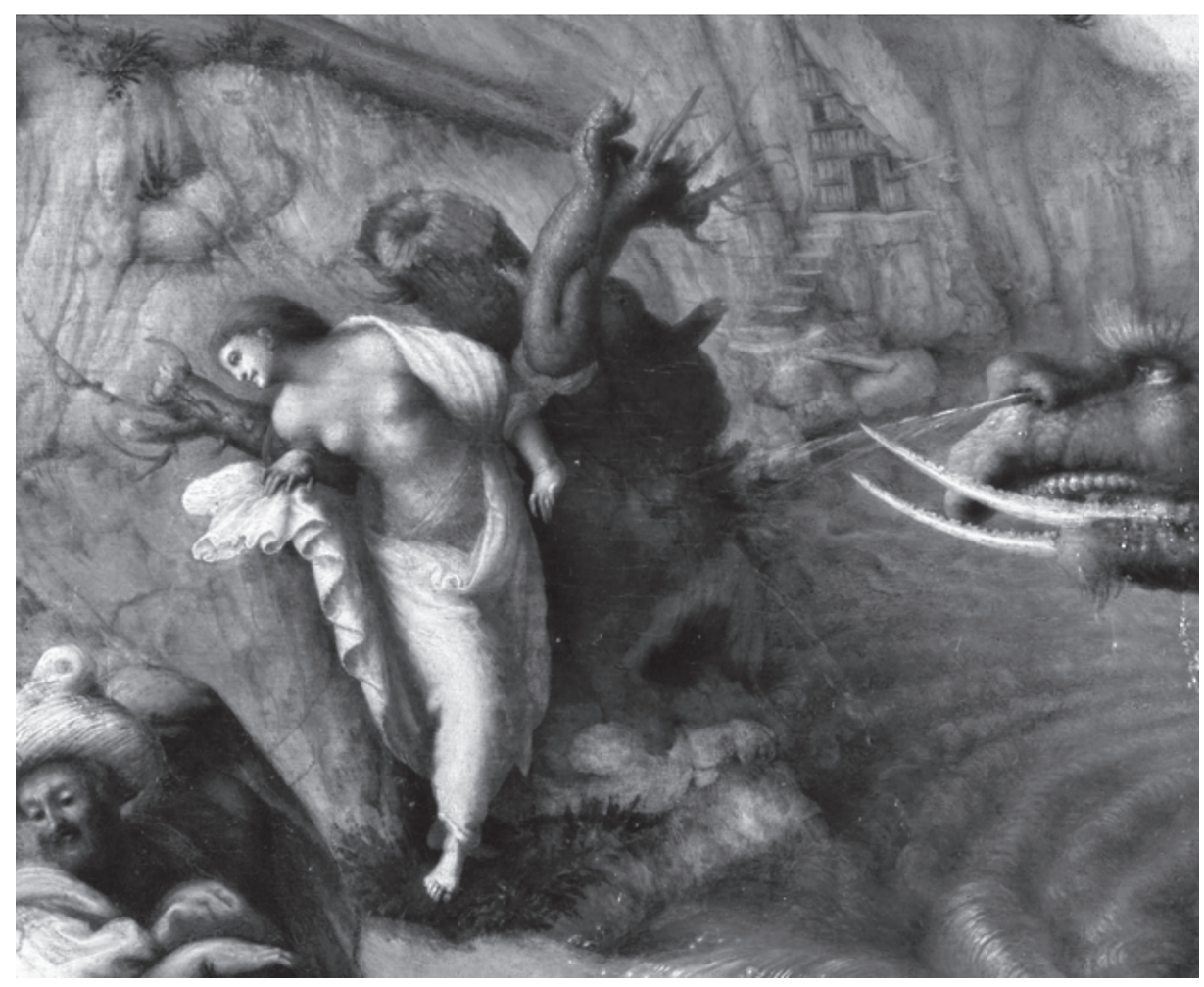

Fig. 9. Piero di Cosimo, detail of Andromeda and broncone, 1515.

The figure of Andromeda in the Belvedere relief was evidently inspired by a painting of 1515 by Piero di Cosimo (Geronimus 2006: 108-115; Hirschauer, Geronimus 2015: 202-204). ${ }^{2}$ His Andromeda is tied to a huge old tree as in a woodcut of 1497 (Bonsignori 1497: e2r; Díez Platas 2015), but with cut-off branches and new shoots sprouting from the stump (Fig. 9). This trunk evokes the broncone, which was one of the emblems of the Medici, who celebrated the indestructibility of their dynasty in this way (Cox-Rearick 1984: 234-235; Walker-Oates 2001; Langdon 2006: 29-30). Although all but one branch has been cut off, that branch may sprout again. The Medici were repeatedly removed from power in Florence, but always regained the city and restored their power. Three years before Piero's image was created, the Medici triumphantly returned to Florence from the exile which they had endured since 1494. Piero's Perseus can be regarded as the alter ego of a member of Medici dynasty, who ended the Republic. Hero slew the monster (Republican establishment) and freed Andromeda (Florence). Andromeda is not chained by iron, as we see in all the later depictions. She is fastened to the tree stump with a ribbon. The stump of the tree (Medici dynasty) does not imprison Andromeda; on the contrary, it provides her with a decorative and protective enclosure.

2 Firenze, Galleria degli Uffizi, inv. 1890, no. 1536. In its time, it was evidently a famous work of art, because early copies are found in the Davanzati Museum in Florence and the Kunsthistorisches Museum in Vienna. In 1568, Vasari (1568: 24) highly praised the painting. 


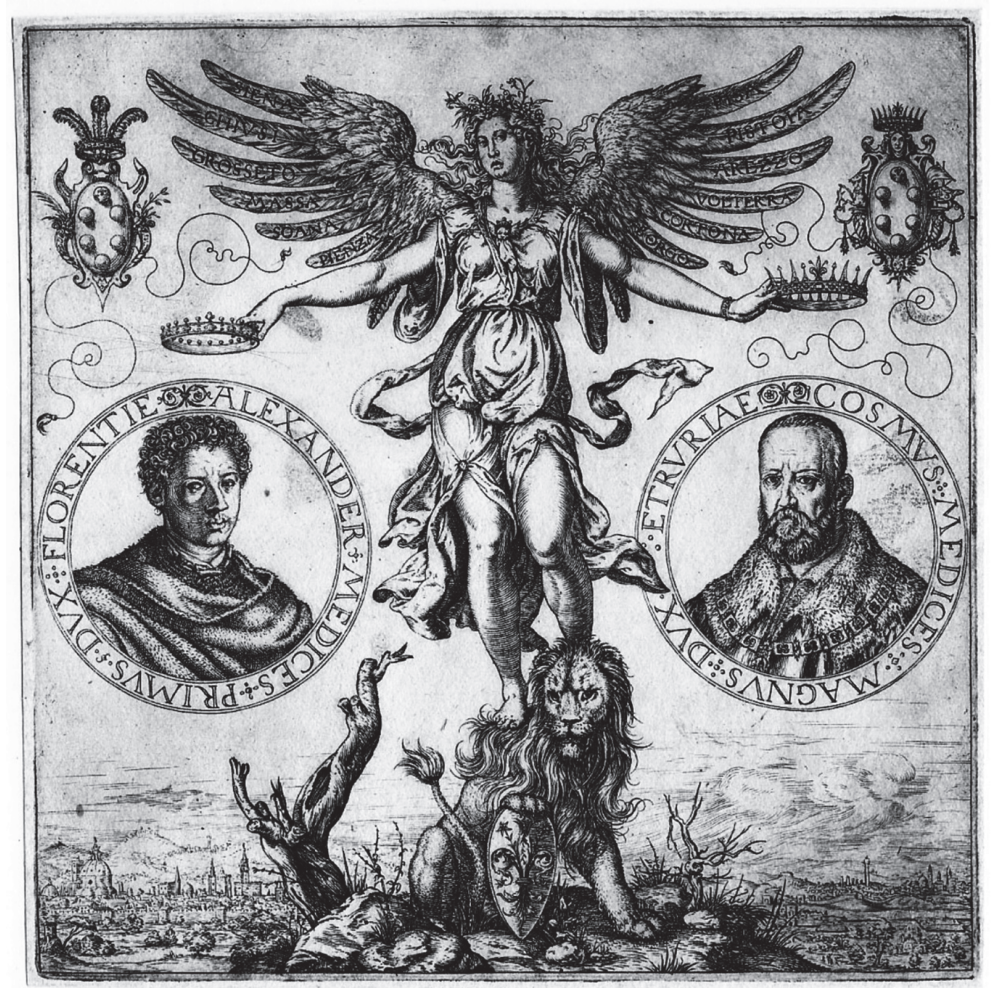

Fig. 10. Martin Rota, Alessandro, and Cosimo de' Medici crowned by a goddess standing on a lion, engraving from 1569-1574. (c) Trustees of the British Museum.

In Piero di Cosimo's image, the broncone is anthropomorphic; we clearly distinguish a face with an open mouth. The focus of the sea monster is not Andromeda, but this face. The dragon (Republican government) seems to be attacking the Princess (Florence), but a stream of water coming out of his nostrils falls not on Andromeda, but on the broncone's face (Medici dynasty). The stream of water has a symbolic meaning. The more a tree is threatened, the more it grows, exactly as in the traditional wisdom, that what does not kill us, makes us stronger.

The motif of the broncone is also found in an engraving by Martino Rota (Fig. 10). In this engraving, we see two Medici rulers of Florence, Alessandro, who ruled from 1531-1537, and Cosimo, who ruled until his death in 1574 (from 1569 as Grand Duke of Tuscany). The Medici broncone appears to the left of the lion: a dead trunk from which only two shoots set off upwards, the first towards the Duke and the second towards the Archduke (Fig. 10). The two sprouts accurately reflect the chronological succession and elevation of the Grand Duchy of Tuscany: Alessandro's broncone is in the lower position; Cosimo's is on top. ${ }^{3}$ In the famous portrait of Cosimo "il Vecchio", the founder of the

3 Alessandro, who ruled in 1531-1537, was the illegitimate son of Lorenzo II. Cosimo Medici, who ruled in 1537-1574, was his distant cousin. On his father's side, he was the great-nephew of the founder of the family, Cosimo. On his mother's side, he was the great-grandson of Lorenzo I. 
dynasty, there is a laurel with one offshoot cut; into the remaining branches, a ribbon is woven (Shearman 1962; Fossi 2004: 112). ${ }^{4}$ On the ribbon, we find the inscription: Primo avulso non deficit alter. It is a quote from Vergil's Aeneid. ${ }^{5}$ The beginning of this quote became a part of the impresa of the Dukes of Tuscany (Ruscelli 1584: 135). On tiles that were produced for the Medici in Robbia's workshop in the second half of the fifteenth century, we find a laurel broncone with the Latin motto "evergreen".

Paolo della Stella's borrowing from Piero di Cosimo presents an enigma. Piero represented a lonely Andromeda tied on the seashore in a way that has no parallels in ancient art. Paolo della Stella adopted the Ancient Roman pictorial type of Perseus untying the Princess (Schauenburg 1981: nos. 67-89). Nevertheless, he replaced the ancient Roman Andromeda type with one drawn from Piero's painting. Why did the sculptor choose this very model in Prague? The reason for this replacement was in all probability that Piero's Andromeda was a bearer of a political message that fitted into Paolo della Stella's overall conception of the decoration of the Prague Belvedere.

On the façade of the Prague Belvedere, one finds similar stumps to which Andromeda is tied, in almost all of the spandrel reliefs. It appears to be an emblem of the patron, an alternative to Medici broncone. Ferdinand I not only created a new State, but was also searching for the visual symbols to promote it (Holzschuh-Hofer 2014). The trimmed tree in the spandrels of the Prague Belvedere may be allegorical references to dynastic succession. Branches wither away or are cut off, but the tree remains. In the same way, when individual members of a ruling family die, the dynasty itself is not endangered (only if it has enough new members).

Perseus and Andromeda might be compared with another spandrel relief, in which Aeneas holds the trunk with cut-off branches while Mercury urges him to leave Carthage (Fig. 11). In Vergil's Aeneid, the divine messenger rebukes Aeneas:

What are you planning? In what hope do you waste idle hours in Libyan lands? If the glory of such a fortune does not stir you, and for your own fame's sake you do not shoulder the burden, have regard from growing Ascanius, the promise of Iulus your heir, to whom the kingdom of Italy and the Roman land are due. ${ }^{6}$

The tree stump next to which Aeneas is standing is a visual image of Mercury's words. If the hero does not think of his son and his future, his family will be like a dead tree stump, from which no new branch grows.

In the relief sculptures decorating the Prague Belvedere, at least one branch is alive, except for the relief sculptures of Perseus Liberating Andromeda, and Aeneas with Mercury. In these scenes we see a dead stump: all the branches have already been cut off. Andromeda and Aeneas might thus be interpreted as counterparts to the living branch of the Medici broncone. Perseus liberated Andromeda, and their descendants founded the Persian Empire, according to Herodotus. ${ }^{7}$ Aeneas left Africa, reached Italy, and his

4 Oil on wood, Florence, Uffizi. The portrait was painted around 1520 by Jacopo Pontormo and ordered by Goro Gheri, secretary of Lorenzo II, who ruled Florence from 1513 until his death in 1519.

Verg. Aen. VI, 143.

Verg. Aen. IV, 271-276, transl. by Fairclough, Goold (1999).

Herodot. VII, 61 and 150. 




Fig. 11. Paolo della Stella, Mercury Orders Aeneas to Leave Carthage, seventh spandrel of the western façade of the Prague Belvedere, sandstone relief sculpture, 1538-1550.

descendants founded the Roman Empire. Andromeda, who is tied to the tree with the cut-off branches, may be interpreted as an allegory of the Jagiellonian dynasty on the Czech and Hungarian thrones. From this dynasty only one member, Anna, remained. That might explain why she is not on a chain, but tied to the tree with a ribbon - the tree stump does not imprison her, but she is its precious embellishment. The large tree trunk of the Jagiellonian dynasty was reduced to only a single live offshoot, Princess Anna. Perseus, the alter ego of Ferdinand I (Bažant 2016), untied Andromeda (Anna) fastened to the old tree with the cut-off branches (Jagiellonian dynasty). Ferdinand I and Anna founded a new dynasty - their son, Maximilian II Habsburg, became Holy Roman Emperor, and he and his descendants continued Ferdinand I's project.

Ferdinand I had every reasons to include the allegory of dynastic succession in the sculptural decoration of the Prague Belvedere. The purpose of this paper was to argue

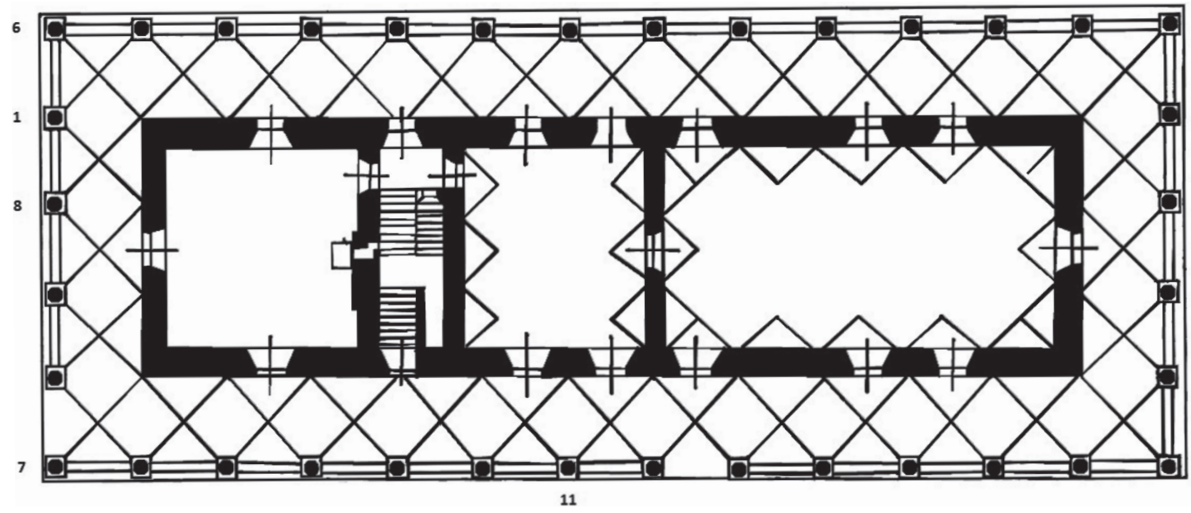

Fig. 12. The ground floor of the Prague Belvedere in its original form of 1538-1550, numbers refer to the Figures in this paper. 
that we may find it in the relief on the second spandrel of its northern façade. The adjoining reliefs, on the left the coat of arms of the Bohemian Kingdom and on the right Perseus liberating Andromeda, might corroborate this hypothesis (Fig. 12).

\section{REFERENCES}

Bažant, J., 2003a. 'Emperor Ferdinand I, Boniface Wolmut and the Prague Castle'. Listy filologické 76, $32-52$.

Bažant, J., 2003b. 'The Prague Belvedere, Emperor Ferdinand I and Jupiter'. Umění 51, 262-277.

Bažant, J., 2005. 'Le Belvédère Pragois de l'empereur Ferdinand Irr. Les aspects politiques du renouveau de «la maison antique » du 16 ème siècle'. Eirene 41, 161-210.

Bažant, J., 2006. Pražský Belvedér a severská renesance [The Prague Belvedere and Northern Renaissance]. Praha: Academia.

Bažant, J., 2016. 'Perseus as Alter Ego of Ferdinand I'. Studia Hercynia 20, 2016, 127-150.

Bažant, J., Bažantová, N., 2014. Pražský Belvedér. První renesanční vila ve střední Evropě [The Prague Belvedere. The First Renaissance Villa in Central Europe]. Praha: Festinalentepress.cz.

Bonsignori, G., 1497. Ovidio Metamorphoseos vulgare. Venezia: Zoane Rosso Vercellese.

Buchholtz, F. B. von, 1968-1971. Geschichte der Regierung Ferdinand des Ersten. I-IX. Um ein Vorwort vermehrter Nachdruck der 1831-1838 bei Schaumburg und Co. in Wien erschienenen Ausgabe. Graz: Akademische Druck- und Verlagsanstalt.

Calvete de Estrella, J. Ch., 2001. El felicísimo viaje del muy alto y muy poderoso príncipe don Phelippe. Ed. P. Cuenca. Madrid: Sociedad Estatal para la Conmemoración de los Centenarios de Felipe II y Carlos V.

Carradice, I. A., Buttrey, T. V., 2007. The Roman Imperial Coinage. Volume II - Part 1. From AD 69 to AD 96: Vespasian to Domitian. $2^{\text {nd }}$ fully rev. ed. London: Spink \& Son.

Chlíbec, J., 2011. Italští sochaři v českých zemích v období renesance [Italian Sculptors in the Czech Lands in the Renaissance Period]. Praha: Artefactum.

Cox-Rearick, J., 1984. Dynasty and Destiny in Medici Art. Pontormo, Leo X, and the two Cosimos. Princeton: Princeton University Press.

Cunnally, J., 1999. Images of the Illustrious. The Numismatic Presence in the Renaissance. Princeton: Princeton University Press.

Díez Platas, F., 2015. 'Et per omnia saecula imagine vivam: The Completion of a Figurative Corpus for Ovid's Metamorphoses in the XVth and XVIth Century Book Illustrations'. In: P. Mack, J. North (eds.), The Afterlife of Ovid [= Bulletin of the Institute of Classical Studies. Supplement 130]. London: Institute of Classical Studies, School of Advanced Study, University of London, 115-135.

Du Choul, G., 1556. Discours de la religion des anciens Romains. Lyon: Guillaume Rouille.

Erizzo, S., 1559. Discorso di m. Sebastiano Erizzo, sopra le medaglie antiche. Venezia: Nella Bottega Valgrisiana.

Erizzo, S., 1568. Discorso di m. Sebastiano Erizzo, sopra le medaglie de gli antichi. Nuovamente ristampato, corretto et ampliato. Vinegia: Appresso Giovanni Varisco \& compagni.

Erizzo, S., c. 1585. Discorso di m. Sebastiano Erizzo Sopra le Medaglie de gli Antichi. Quarta editione. Vinegia: Appresso Gio. Varisco \& Paganino Paganini.

Fairclough, H. R., Goold, G. P., 1999. Virgil, Eclogues. Georgics. Aeneid, Books 1-6. With an English translation by H. R. Fairclough, revised by G. P. Goold. Cambridge, MA: Harvard University Press.

Fossi, G., 2004. Uffizi. Firenze: Giunti.

Geronimus, D., 2006. Piero do Cosimo. Visions Beautiful and Strange. New Haven: Yale University Press.

Hirschauer, G. A., Geronimus, D. (eds.), 2015. Piero di Cosimo. The Poetry of Painting in Renaissance Florence. Washington, D.C.: National Gallery of Art.

Holzschuh-Hofer, R., 2014. 'Ikonologie der Hofburg'. In: H. Karner (ed.), Die Wiener Hofburg. 1521-1705. Baugeschichte, Funktion und Etablierung als Kaiserresidenz. Wien: Verlag der Österreichischen Akademie der Wissenschaften, 530-548. 
Kalina, P., Kotátko, J., 2011. Praha 1437-1611. Kapitoly o pozdně gotické a renesanční architektuře [Prague 1437-1611. Chapters on Late Gothic and Renaissance Architecture]. Praha: Libri.

Langdon, G., 2006. Medici Women. Portraits of Power, Love, and Betrayal. Toronto: University of Toronto Press.

Ruscelli, G., 1584. Le imprese illustri. Venezia: F. Rampazetta.

Schauenburg, K., 1981. 'Andromeda I'. In: Lexicon Iconographicum Mythologiae Classicae I/1. Zürich / München: Artemis Verlag, 774-790.

Seipel, W. (ed.), 2003. Kaiser Ferdinand I. 1503-1564. Das Werden der Habsburgmonarchie. Eine Ausstellung des Kunsthistorischen Museums Wien, 15. April bis 31. August 2003. Milano: Skira.

Shearman, J., 1962. 'Pontormo and Andrea Del Sarto, 1513'. The Burlington Magazine 54, 478-483.

Vasari, G., 1568. Delle vite de' piu eccellenti pittori, scultori et architettori. Firenze: Giunti.

Vico, E., Zantani, A., 1548. Le imagini con tutti i riversi trovati et le vite de gli imperatori tratte dalle medaglie et dalle historie de gli antichi. Libro primo. Venezia: [s. n.].

Vico, E., 1554. Omnium Caesarum verissimae imagines. Venezia: Paolo Manuzio.

Walker-Oates, V., 2001. 'Representing the Perfect Prince. Pontormo's Alessandro de' Medici'. Comitatus. A Journal of Medieval and Renaissance Studies 32, 127-146.

\section{LIST OF FIGURES}

Fig. 1. Paolo della Stella, Allegory of Dynastic Succession, second spandrel of the northern façade of the Prague Belvedere (from left to right), sandstone relief sculpture, 1538-1550. Plaster cast made in 2007, photo by courtesy of the Heritage Conservation Department of Prague Castle.

Fig. 2. Paolo della Stella, Allegory of Dynastic Succession (partial reconstruction indicating the possible position of fingers holding the globe), 1538-1550 (drawing Nina Bažantová).

Fig. 3. Incorrect reconstruction of the reverse of the sestertius of Titus minted in $80-81 \mathrm{AD}$, woodcut (Erizzo 1559: 195).

Fig. 4. Coin with Vespasian and Titus holding a globe minted in 80-81 AD, woodcut (Vico, Zantani 1548: 51).

Fig. 5. Coin with Vespasian and Titus holding a globe, woodcut (Du Choul 1556: 68).

Fig. 6. Paolo della Stella, shield with the Bohemian lion, first spandrel on the northern façade of the Prague Belvedere, sandstone relief sculpture, 1538-1550 (photo author).

Fig. 7. Paolo della Stella, shield with monogram: FA (Ferdinand and Anna), sixth spandrel on the northern façade of the Prague Belvedere (from left to right), sandstone relief sculpture, 1538-1550 (photo author).

Fig. 8. Paolo della Stella, Perseus Liberating Andromeda, third spandrel of the northern façade of the Prague Belvedere, sandstone relief sculpture, 1538-1550. Plaster cast made in 2007, photo by courtesy of the Heritage Conservation Department of Prague Castle.

Fig. 9. Piero di Cosimo, detail of Andromeda and broncone, 1515.

Fig. 10. Martin Rota, Alessandro, and Cosimo de' Medici crowned by a goddess standing on a lion, engraving from 1569-1574. () Trustees of the British Museum.

Fig. 11. Paolo della Stella, Mercury Orders Aeneas to Leave Carthage, seventh spandrel of the western façade of the Prague Belvedere, sandstone relief sculpture, 1538-1550. Plaster cast made in 2007, photo by courtesy of the Heritage Conservation Department of Prague Castle.

Fig. 12. The ground floor of the Prague Belvedere in its original form of 1538-1550, numbers refer to the Figures in this paper. 
ALEGORIE DYNASTICKÉ POSLOUPNOSTI NA BELVEDÉRU V PRAZE (1538-1550)

Článek analyzuje unikátní reliéf na Belvedéru v Praze, který zbudoval Ferdinand I. Reliéf zobrazuje starého muže na koni, který předává globus před ním stojícímu mladému muži. Výjev lze chápat jako alegorii dynastické posloupnosti. Sousední reliéfy tuto hypotézu potvrzují, nalevo je znak Českého království a napravo Andromeda, kterou osvobozuje Perseus, alter ego Ferdinanda I.

\section{Jan Bažant}

Institute of Philosophy, The Czech Academy of Sciences, Prague; Trnava University in Trnava

bazant@ics.cas.cz 